\title{
Creative Thinking and Decision-Making Processes in EFL Creative Writing
}

\author{
ABSTRACT
}

Creativity has been discussed, observed and researched for hundreds of years in the fields of psychology and philosophy - from the ancient notion of the inspired genius, all the way to modern psychologists trying to define creativity and prove its effects. Creativity has recently become a buzzword in EFL teaching practices. We try to stimulate creative thinking in the classroom, but possibly forget to observe the processes within it. The article discusses definitions of creativity and presents a qualitative study on the decision-making processes within EFL creative writing and its connections to students' language learning. The qualitative study was conducted with two 3rd-year bachelor English students who were asked to plan and write a short story in English while doing a think-aloud protocol. The data were transcribed and coded in order to observe emerging categories in the students' reasoning for plot and language use decisions.

Keywords: EFL; creative writing; creative thinking; decision making; language learning

\section{Kreativno mišljenje in procesi odločanja pri ustvarjalnem pisanju $v$ angleščini kot tujem jeziku \\ POVZETEK}

Kreativnost je predmet razprav, opazovanj in raziskav v psihologiji in filozofiji že stoletja; od starodavnih idej navdihnjenega genija pa vse do poskusov modernih psihologov, ki želijo kreativnost definirati in pokazati njene učinke. Nedavno je kreativnost postala tudi ena izmed novih popularnih tem in ciljev poučevanja angleščine. To vse vodi $\mathrm{v}$ željo po stimuliranju kreativnosti $\mathrm{v}$ razredu, vendar pa pri tem pozabimo opazovati procese znotraj kreativnega mišljenja. Članek skuša pokazati nekatere aspekte odločanja pri kreativnem pisanju v tujem jeziku in kako se ti potencialno odražajo pri učenju jezika. Kvalitativna študija je bila izvedena $s$ študentoma angleščine tretjega letnika dodiplomskega študija, ki sta načrtovala in napisala kratko zgodbo v angleščini in pri tem glasno opisovala svoje miselne procese. Podatki so bili transkribirani in obdelani tako, da so se izluščile odločitve o rabi jezika in poteku zgodbe, ter razlogi zanje.

Ključne besede: poučevanje angleščine; kreativno pisanje; kreativno mišljenje; odločanje 


\section{Creative Thinking and Decision-Making Processes in EFL Creative Writing}

\section{Introduction}

Creativity is everywhere; in the way we see, observe and solve practical problems all the way to creating things for the sake of their aesthetics. In recent years, the field of foreign language teaching has begun to see creativity's potential for the foreign language classroom as well as the necessity for it due to the increasing value it is gaining in the world of employment (Mumford and Simonton 2011). It has become our responsibility as foreign language teachers to provide creatively stimulating teaching and thus better prepare our students for life beyond the classroom. Creativity has become a buzzword in ELT research, but studies focusing on what is actually going on inside the creative thinking process when it meets English as a foreign language are still few and far between.

One of the interesting questions here is how we can ultimately improve the use of creativity in the EFL classroom by first observing and understanding how a student's creative thinking links to foreign language learning and how it potentially informs that process. The benefits of being creative and knowing how to think creatively are obviously present, but how do they connect to language learning? This study explores the processes within creative thinking, foreign language use, and creative writing in order to get better insight into and thus further develop this particular topic.

Creative writing is an activity that naturally lends itself to producing creative thinking, language use, and enhancement of students' personal development in general (Dai 2010). Thus, it was chosen in this study to provide stimulation. It prompts students to use their language in a special and personal way. They have to use the knowledge they have about language and writing in general, but they can also express themselves and their inner world.

\section{Creativity}

In order to understand creative processes and their characteristics, a closer look at some of the definitions and explanations of creativity needs to be taken. The following definitions illustrate some of the main points of today's understanding of creativity. First there is the observation that creativity is simply useful innovation (Cropley 2001). Cropley provides a condensed two-word definition that only begins to scratch the surface. Creativity certainly contains the elements of novelty and usefulness, but all of its stages and interactions between those make it an enigma that needs further study and elaboration. Another attempt at defining creativity states that it is the "ability to come up with new ideas that are surprising yet intelligible, and also valuable in some way" (Boden 2001, 95). Again, the focus is on the end result, but the long and complex road to that goal is not addressed. These abbreviated explanations neglect the element of the process. One of the researchers dealing with creativity did at some point mention different types of thinking in the definition (Tin 2013) but the need for a more detailed definition remains.

There is no presumption here that the following definition will include everything there is to creativity, which would indeed be impossible. However, I do try to include the process and its complexity. Creativity is thus, from my point of view, a complex cognitive process of trying to identify as well as solve a problem through a myriad of intertwined thought processes that occur 
and reoccur at different stages of the creative process, aiding and changing each other, while interacting within the bigger system of solution finding in order to produce something new, surprising, useful and/or valuable. This definition took shape through my learning about the process models of creativity further elaborated on below. It was also shaped through the research process itself, when the creative writing was taking place and the stages, their occurrence and reoccurrence could be observed.

\subsection{Categories of Creative Magnitude}

In deciding to include creativity in every day teaching, another issue needs to be considered, namely, the categories of creative magnitude, which distinguish between creativity with a big $\mathrm{C}$ and creativity with a small c (Csikszentmihalyi 2009). The distinction between the two is aptly explained by Kozbekt et al. $(2010,23)$ :

Big-C Creativity refers to unambiguous examples of creative expression (e.g., Dickinson's poetry, Coltrane's jazz, Freud's psychology). In contrast, little-c creativity focuses on the creativity of everyday life (Richards, 2007) - experiences and expressions accessible to almost anyone, for example, the novel way a home cook includes ingredients in a recipe, which is later praised by family and friends.

Big C was, throughout history, always the ultimately sought after revelation, the thing that nobody thought of and saw before. Society and world changing ideas were long viewed as the only true creativity and were only found in the ranks of geniuses. Pre-Christian, Buddhist, and Hindu societies saw it as an act of the divine and the later western worlds interpreted creativity based on the Biblical story of creation in Genesis, sparking the idea of creative people being God's artisans (Runco and Albert 2010). Today's world has come to see the value of small-c and it is from this appreciation that the practice of teaching everyone how to utilise their creative potential emerged.

\subsection{The Processes of Creative Thinking}

In 1950, Guilford first brought creativity to the forefront within the science world and, following his work, in 1958 Torrance published his test of creativity, which was focused on measuring divergent thinking, in an attempt to find the most gifted children and measure their potential. There were many other ways and refinements of creativity measurement that later followed and that measured different aspects of creative thinking, such as Wallach and Kogan, Hall and MacKinnon or Carson, Peterson and Higgins (Kaufman and Sternberg 2010), but ultimately there seem to be so many facets of creativity to measure and so much controversy as to what and how these tests measure that they remain an ever emerging point of discussion. This again indicates the complexity of what creativity actually is and how much more observation needs to be undertaken in order to understand it and apply it usefully in the classroom. This study aims to shed light on at least a fraction of the processes that occur in creative thinking and foreign language learning.

With the revelation of so many facets and stages of creative thinking an investigation of the processes involved is in order. The four-stage model of the creative process (Guilford 1950) was presented early on in some introspective accounts of the creative act. For example, at the end of the 19th century, Hermann von Helmholtz, the physicist and physiologist, described how after investigating a problem thoroughly, "happy ideas came unexpectedly without effort, like an inspiration" (Wallas 1926, 80). Once the four-stage model base was established, several additions 
and updates emerged. For example, in a relatively recent proposal, Amabile (1996) incorporated a version of the basic stage model into her componential model of creativity. The creative process is described as consisting of several phases: (a) problem or task identification, (b) preparation (gathering and reactivating relevant information and resources), (c) response generation (seeking and producing potential responses), and (d) response validation and communication (testing the possible response against criteria). A final phase of decision making about further work is proposed: based on the outcome of response validation and communication, a person may either stop because a successful product is achieved, stop due to failure, or return to one or more phases in the process for further work. These stages, which do not necessarily occur in a fixed sequence, describe the creative process in individuals and small groups (Amabile 1996).

Other models suggest extending or enhancing the basic four-stage model, pointing out that it is important to distinguish the problem formulation phase from the preparatory phase in which relevant information is gathered, and separating those further from other phases of the creative process. Some have suggested that a phase of frustration occurs after the preparatory phase when the analytic mind reaches its limit in dealing with the problem; frustration may provoke incubation (Goleman et al. 1992). There was another opposed stream of researchers who did not believe in the stage model at all. Eindhoven and Vinacke (1952) found no evidence supporting four discrete stages in the creative process; they described the creative process as a dynamic blend of processes that co-occur, in a recursive way throughout the work. In addition, the creative process varied from one individual to another.

If we move on from creativity itself to its aspects in the EFL classroom, we encounter a varied assembly of teaching and learning facets combined with creativity. For example, Cropley, who advocates creativity in education in general, talks about stimulating and fostering creativity in educational environments and explains ways in which to do that (Cropley 2001); there is also plenty of discussion on creativity in teachers and their methodology (Widodo and Cirocki 2013) and studies published on the aspects of combining creativity and learning standards (BurkeAdams 2007). The list goes on, but the knowledge on creative thinking in the EFL class still seems to be in need of expansion.

\subsection{Creative Writing in ELT}

L2 writing research often deals with non-creative writing and its stages (all composition incorporates some creativity, but non-creative writing here refers to the writing of text types other than novels, short stories, poetry, etc., generally referred to as creative writing). For example, Raimes's study (1985) dealt with L1 and L2 unskilled writers and their similarities and differences in composing a text on something unexpected that had happened to them. Students were asked to do retrospective think-alouds. She looked for categories such as language, audience awareness, and time spans of writing and came to the conclusion that there are not as many differences in L1 and L2 composition as expected, and that the L2 learners actually seemed to make more of an effort. This study was examined in order to see whether there were some clues as to how the L2 writing process is different or special; although it did not deal with creative composition, it did display some similarities with the observed writing process in the presented study.

Many studies on creative writing are linked to literature in the classroom since there is a strong connection between reading and writing (Spack 1985). There are also studies involving corpus based learning to enhance ESL writing, but it seems as though creative writing and the processes 
within largely remain a domain of native speakers majoring in English, which I think is a big loss for foreign language learners.

The above overview shows the necessity to start filling the gaps in our knowledge as to how our students go through these creative processes, in order to better understand their thinking. The goal of the presented study is to answer the question of what the students' reasoning is behind their decisions when creative writing occurs, and what that can possibly indicate about their foreign language learning.

\section{Methodology}

\subsection{Think-Aloud Protocols}

The applied research method was concurrent metalinguistic think-aloud protocols or verbal reports. Think-loud protocols are a learner's comments recorded while he or she completes a task. They have been used as a research tool since the early twentieth century - by Ewert and Lambert in 1932 and Kantona in 1940. They started off as the researcher's additional thought explanations to participants and later became the thought explanations of the participants themselves in the 1950s (Bowles 2010). They have been used in a wide range of fields, such as psychology, L1 and L2 research and translating, and are now recognised as a major source of data on subjects' cognitive processes in specific tasks (Ericsson and Simon 1993).

The main two categories are concurrent think-aloud protocols and retrospective reports. The discussions surrounding the two reports express a concern with the challenge of veridicality in retrospective reports, meaning that subjects studied could forget what they were thinking about by the time they had to explain their thought process. This problem was addressed by Gass and Mackey who proposed to minimise this loss of information with short delays between tasks and verbalization or by recording and videotaping the participants and thus enabling them to see their performance and remember their thought process (Gass and Mackey 2000). For the specific reason of veridicality loss, I use concurrent think-alouds, as they were the most appropriate for the study at hand. In fact there are so many decisions involved in planning and writing a short story that any other approach seemed to present a substantial risk for data loss.

I shortened the prompting of participants to speak their thoughts to an interval of one minute, as it became evident that the participants sometimes needed only 30 to 50 seconds to make big plot leaps while planning the story. There is no evidence of the fact when these ideas were cognitively formed and processed within a non-commenting phase, but it is evident that longer prompting intervals could mean data loss. For example, participant one came up and refined an entire scene within his flow of reporting, he did not have any long pauses, and he produced the following idea:

She left the door open so she runs back, let's say they have a house, home, house OK, so I can make it that easier if she's not petrified but scared, she runs up the stairs ... hm ... oh yeah, she runs up the stairs, she's trying to run up the stairs, the girl kinda appears at the top of the stairs, that's good.

After this report, the student wrote: "appears at the top of the stairs." I believe that if he had paused and had been left to ponder this without reporting for longer than 30 or 60 seconds, a lot of the reasoning would have been lost. 
Further classifications undertaken by Ericsson and Simon (1993) added two additional categories which were used in SLA research, namely, (1) non-metalinguistic protocols, where subjects have to verbalise thoughts per se, and (2) metalinguistic protocols, where subjects have to verbalise additional information about the thoughts such as explanations and justifications (see also Bowles and Leow 2005). All the mentioned protocols were subjected to investigation by looking at studies which dealt with the reactivity for latency and accuracy in think-aloud and silent task completion. Although these are not directly applicable to the presented study, as our activity did not aim for one specific answer, they are still valuable indicators that there has been some reactivity with latency (the execution time of a task is prolonged due to the fact that the reasoning needs to be explained). This complication can, in my opinion, be solved simply by giving participants more time to do a task, but it shows no significant reactivity for accuracy. Researchers like Ellis (2005) and Jourdenais (2001) pointed out that metalinguistic protocols do present an additional task and could be even more reactive than the non-metacognitive protocols. Yet only six studies have used verbal tasks, which limits the relevance for SLA studies, and no conclusions were made to show any relevant detriment to data collection with metacognitive protocols. The problem of reactivity due to metacognitive protocols was addressed in this study by making sure that the participants were instructed to try and share their thoughts. They were told not to get preoccupied with the articulation of the thoughts, as they would be reminded by the researcher to share their thoughts at regular intervals.

Certain controversies surround the validity of think-aloud protocols. The main issue is that it cannot fully capture every thought the study subject has, but it is the closest to observing and recording the thought process that we know to date and no other valid data collection tool exists that could capture the thought process of an individual. SLA researchers have therefore taken the stand of psychologists Ericsson and Simon, as psychology was the first field to utilise them, and deem verbal protocols to be a tool that accurately enables insight and does not interrupt the thought process in so far as to make the reporting invalid (Bowles 2010).

As with every research choice, we cannot choose our methodology tools without the context of the problem. For this particular study, a metalinguistic metacognitive think-aloud protocol seemed to be the most fitting research tool to observe the creative reasoning during the activity and the reasoning behind the language and plot choices.

\subsection{Equipment and Software}

The equipment was an Apple MacBook Pro (13-inch, Mid 2012) and the microphone was attached to a Logitech USB Headset H340. The headset was chosen because it enables the participants to use their hands freely as they needed to write. The recording quality was good and clear and the recordings were normally intelligible.

The recording software was Audacity 2.0.6. The software is freely accessible and only needs one additional add-on for manipulating .wav and .mp3 formats. It also enables a manipulation of speed and tempo of the recording if necessary.

\subsection{Transcription}

All the recordings were transcribed by me with several re-examinings in order to ensure accuracy. Interruptions were recorded if present during the questioning and probing by the researcher and were transcribed in dialogue form and the rest were mainly the participant's monologues. Pauses, filling sounds, slang usage and mistakes were transcribed as they occurred. 


\subsection{Data Collection}

The data collection took place at the University of Maribor, Faculty of Arts, with two 3rd year students from the English language and literature Bachelor's programme. Both students were presented with the main points of the research along with its aims, and after receiving all the information they signed a consent form on the day of the data collection. The consent form includes details about the researcher, contact details and the aim of the study, as well as the guarantee that participants will stay anonymous and have the right to withdraw from the study prior to any publications.

Participants were given an activity sheet with the picture prompt and the instructions, which were read and discussed to make sure everything was clear. The instructions clearly stated the context, aim and scope of the activity, namely, writing a short story for their university newspaper. They were also informed that they were allowed to use their L1 if they felt the need to do so as was suggested in the literature in order to avoid any data loss (Bowles 2010). The logic behind it was that if the students could not find the words to express themselves in their L2, allowing them to do so in their L1 would still ensure the thought to be expressed.

Both participants first underwent a test activity where they had to title two pictures. The participants seemed confused as to what to say and what not to say, so they were kindly reminded not to worry about filtering, as everything that went on in their minds was valid and that I wanted to hear it. At this point it would be fitting to point out that think-alouds can be quite intimate and that creating a relaxed atmosphere is very important, as sharing one's thoughts can be very personal. It is important to make the participants feel safe and respected. After some initial hesitation, I helped out with some questions and the participants grasped the concept of the think-aloud and proceeded to share their thoughts and ideas on how to title the picture and what their reasoning behind it was. During the test activity, they were briefly familiarised with operating Audacity in case they wanted to pause or stop the recording.

Participants had 45 minutes for story planning and 60 minutes for story writing. As it is my belief that creative processes suffer under time restrictions (which I will briefly comment on later in the discussion section), I stayed flexible with the time limit and allowed the first participant to take more time in planning and writing, but neither of the time limits were overdrawn by more than 15 minutes. We still have to consider that in a normal situation in the ELT classroom, we would not have infinite time at our disposal. The second participant only took 30 minutes to plan the story and took an hour and 10 minutes to write as she preferred to review the content of the story while actually writing it. The second participant also insisted on proofreading her story before submitting it. They both took 15 -minute breaks during the recording process and were free to determine when the breaks started to ensure they had some rest when they felt they needed it.

When the recording was taking place, the participants had to be reminded several times to keep reporting what they were thinking about. The first participant received much less reminding, as he was more verbose in expressing his thoughts, and because it was not clear at this point if more probing would be necessary, or if it would overly interfere with the data. The second participant had to be encouraged to report on her thinking more often, because she was less talkative than the first participant. The probing questions were asked after 60 seconds of silence and were often aimed towards thoughts on language, as the first candidate mentioned thoughts on language much less frequently than expected. The second candidate did not display any more preoccupation with the language despite the more frequent questions about it. 


\section{Data Analysis}

The data analysis itself was done by studying and coding the transcribed texts with the occasional help of the recordings for clarification. Initially, categories on content decisions were marked in bold and categories and comments were written in the note review option of MS Word. Any content decisions connected to the story that were also elaborated upon, were marked bold and then further divided into categories, on which the decisions were based. All of those were placed in a table for better visibility and the number of categories was reduced and unified for both participants in order to make the emerging categories more visible and manageable. The unification took place when two categories were initially describing the same thing in different words, for example: 'Says he chose the development to make the story more realistic' and 'Thinks he has to describe the character better to make the story more realistic' or 'She is asking if the word axe is right for the object in the picture' and 'guessing about vocabulary'. The categories that proved to be present in both participants were put in Table 3 , as were the numbers of their occurrences.

TABLE 1. Content decisions - developing matching categories (I symbol: number of occurrences plus one - the written occurrence).

\begin{tabular}{|c|c|}
\hline Participant 1 & Participant 2 \\
\hline $\begin{array}{l}\text { Decision based on trying to avoid clichés, the ex- } \\
\text { pected or ordinary. } \\
\text { I }\end{array}$ & $\begin{array}{l}\text { Decision based on trying to avoid clichés, the } \\
\text { expected or ordinary. II }\end{array}$ \\
\hline Decision based on picture prompt. II & Decision based on picture prompt. II \\
\hline Personal preference. II & Decision based on personal preference. \\
\hline Does not have an explanation for decision. III & Decision based on previous knowledge. \\
\hline $\begin{array}{l}\text { Decision based on the desire to make the story } \\
\text { interesting. IIIIIIIIIII }\end{array}$ & $\begin{array}{l}\text { Decision based on the desire to make the story } \\
\text { interesting. }\end{array}$ \\
\hline $\begin{array}{l}\text { Decision based on beliefs about the target lan- } \\
\text { guage's culture. }\end{array}$ & $\begin{array}{l}\text { Decision based on the knowledge of one deci- } \\
\text { sion bringing a whole lot of consequences to } \\
\text { the narrative. }\end{array}$ \\
\hline${ }^{*}$ Comments on his own decision/idea. II & $\begin{array}{l}\text { Decision based on trying to make the story } \\
\text { more mysterious. }\end{array}$ \\
\hline Decision based on fiction reasoning. & Decision based on fiction reasoning. \\
\hline & ${ }^{*}$ Comments on his/her own decision/idea. I \\
\hline $\begin{array}{l}\text { Real life reasoning. IIIIIIIIIIIIIIIIIIIIIIII } \\
* \text { Oyerrides the guestion and continues with creat- }\end{array}$ & Decision based on fiction reasoning. \\
\hline $\begin{array}{l}\text { ing the plot (as if it is already in the flow, is more } \\
\text { important, worries about losing the ideas.) I }\end{array}$ & Decision based on time limit. III \\
\hline Decision based on wanting to make the story & Decision based on real life reasoning. I \\
\hline 'unusual'. I & $\begin{array}{l}{ }^{*} \text { Overrides the question and continues with } \\
\text { creating the plot, as if it is already in the flow, is } \\
\text { more important, worries about losing the ideas. }\end{array}$ \\
\hline
\end{tabular}




\begin{tabular}{|c|c|}
\hline Participant 1 & Participant 2 \\
\hline $\begin{array}{l}\text { Decision based on the desire to make the story } \\
\text { more realistic. IIIIII }\end{array}$ & $\begin{array}{l}\text { Describes little details so they fit into the main } \\
\text { theme and finds a contrast in pale. }\end{array}$ \\
\hline $\begin{array}{l}\text { Decision based on a previous decision on the } \\
\text { plot. }\end{array}$ & $\begin{array}{l}\text { Decision based on the desire to make the story } \\
\text { more realistic. }\end{array}$ \\
\hline *Seems to be 'surprised' by his own idea. I & Introduces idea and then abandons it. \\
\hline $\begin{array}{l}\text { Decision based on trying to make the story scary. } \\
\text { IIIII }\end{array}$ & $\begin{array}{l}\text { Realised that she had an idea and then forgot } \\
\text { about it. }\end{array}$ \\
\hline $\begin{array}{l}\text { Decision based on the desire to make more dra- } \\
\text { matic. I } \\
\text { Personal opinion. IIIIII }\end{array}$ & $\begin{array}{l}\text { Decision based on story flow reasoning. } \\
\text { Skips description probably because of the time } \\
\text { limit. }\end{array}$ \\
\hline Decision based on wanting to create variety. I & \\
\hline $\begin{array}{l}\text { Decision based on expectation of possible chang- } \\
\text { es. }\end{array}$ & \\
\hline Tries an idea and abandons it. I & \\
\hline $\begin{array}{l}\text { Decision based on trying to make the story more } \\
\text { vivid. }\end{array}$ & \\
\hline $\begin{array}{l}\text { Decision based on narrative reasoning (driving } \\
\text { the story forward) }\end{array}$ & \\
\hline $\begin{array}{l}{ }^{* *} \text { Actual interaction between content creating } \\
\text { and language. First he tries to find a name for the } \\
\text { girl's sleeping problems, if he cannot name it in } \\
\text { English, it cannot stay in the story. }\end{array}$ & \\
\hline Decision based on wanting to build suspense. & \\
\hline $\begin{array}{l}\text { ** Further linguistic changes to make names } \\
\text { clearer and concurrent within the story and thus } \\
\text { make the plot easier to follow. }\end{array}$ & \\
\hline $\begin{array}{l}\text { Change of content to fit further development. - } \\
\text { Did he think of that 'she's gonna talk about this } \\
\text { tomorrow' or had the brain pre-formed a story } \\
\text { before? }\end{array}$ & \\
\hline
\end{tabular}

The emerged and combined categories and the numbers of their occurrences for both participants will be presented below in the results section.

\section{Results}

The results of the content-based decisions were examined and produced some combined categories in both participants. The emerging categories, which seemed to have a connection to language learning, were elaborated upon. 
The codes accompanied by the * symbol indicate an observation outside the decision making tied to the story's content.

TABLE 2. Content decisions - matching categories.

\begin{tabular}{|l|l|}
\hline Emerged coding categories for both participants & Number of occurrences \\
\hline $\begin{array}{l}\text { Decisions based on trying to avoid clichés, the expected or ordi- } \\
\text { nary. }\end{array}$ & 5 \\
\hline Decisions based on picture prompt. & 6 \\
\hline Decisions based on personal preference. & 4 \\
\hline Does not have an explanation for decision. & 4 \\
\hline Decisions based on the desire to make the story interesting. & 13 \\
\hline Decisions based on time limit. & 8 \\
\hline Decisions based on fiction reasoning (fiction 'anything goes' logic). & 2 \\
\hline *Reflecting on their own decision/idea. & 10 \\
\hline Decisions based on real life reasoning (realistic logic). & 26 \\
\hline $\begin{array}{l}* \text { Overrides the question and continues with creating the plot, like } \\
\text { it's already in the flow, is more important, worries about losing the } \\
\text { ideas. II }\end{array}$ & 3 \\
\hline Decisions based on the desire to make the story more realistic. & 8 \\
\hline *Tries an idea and abandons it. & 3 \\
\hline *Change of content to fit further development. & 2 \\
\hline
\end{tabular}

Table 2 presents the emerged categories from the story's content based decisions. Thirteen categories emerged, of which 'Decision based on the desire to make the story interesting' is the most frequent, along with 'Decision based on fiction reasoning.' The next step will be to elaborate on what types of decisions were coded into what category and what implications that could have for the two participants in their foreign language learning.

The category 'Real life reasoning' was coded each time the participants based their reasoning on real life logic. For example, creating the main character as a mediocre student so her parents demand that she stay after school, more precisely after nightfall, which the participant deems as the perfect time for scary things to happen. This category could illustrate how the creative process is still governed by our knowledge of the real world and does not enter into realms of complete disconnection from reality. It could also show a connection to the participant's knowledge of the target language's culture, since a lot of the decisions, especially with participant number one, were based on general knowledge about the American school system. The participant included a cultural reference to the English speaking world by including the concept of having to stay after school, which does not occur in the Slovene school system.

'Decisions based on trying to avoid clichés, the expected or ordinary.' This reoccurring category was applied whenever the participants explained their decisions to be made on the base of wanting to avoid the ordinary clichés and plot twists that they already know from real life or 
fiction. This could be an indicator of what creativity in narration and language use actually means to them. This is definitely an important part for them as EFL learners, for their attitudes towards creativity definitely fuel their motivations to write and what choices they make in their L2 or L1 writing. The implication we could take from that as teachers is the fact that students who do a creative writing task actively seek alternative ways of expressing situations, plot twists or moods in a story to avoid clichés. With this, students get motivated to search their brain for vocabulary, phraseology and grammatical structures they usually do not apply in their foreign language writing, so by using creative writing in class, we might be able to trigger the motivation for using alternative ways of language use.

'Decisions based on personal preference.' I believe that this is one of the most important aspects of creative writing in L2. It is my belief that creative writing enables students to put themselves into the text in a way that cannot be done in other forms of writing. It provides a perfect channel for letting their audience know what they see as creative, interesting, intriguing, etc., and teachers are provided with an excellent tool for getting to know their students through their creative outlet, thus enabling them to better assist the students in their learning. If the teacher observes reoccurrences of certain themes and topics in a student's creative writing, they might use those to develop more material around those or assign individually tailored work around that topic for students who struggle and need to do extra work. Doing that through a student's special interest might make the extra work more interesting and less tedious.

'Decisions based on the desire to make the story interesting and decisions based on the desire to make the story more realistic.' The students seem to be trying to entertain their readers and make the stories more believable for them, which is again important information for ESL teachers. It clearly shows that they use their imagination and creativity to fulfil the tasks given to them in order to practice or learn a foreign language, and do not see them just as a drill; they consider their imaginary audience and use the language to communicate. For our teaching that might indicate that creative writing activities can provide our students with opportunities for communication reflexion. They get the chance to consider what their audience wants to hear and how they can achieve this through their language, making them better communicators in any language.

'Decisions based on time limit.' Both participants worked around and actively complained about the lack of time at their disposal. As the classroom reality presents a limit in time, which might be detrimental to the creative process, we might consider doing more demanding creative activities as a class project or extended homework projects. We might also choose specific creative activities in class that take notice of timeframes and that can provide the students with a sense of satisfaction despite the time limit.

'Decisions based on fiction reasoning (fiction 'anything goes' logic).' It was very interesting to note that the participants seemed to find a challenge and a relief in the fact that they had free rein from reality. Both participants made sure that the story had a supernatural element, but that it still made sense within a realistic context. This indication is a valuable piece of information for the ELT classroom: it might indicate that students enjoy writing activities that allow them to stretch their imagination beyond everyday normality, giving us the opportunity to use them as a welcome change and motivation in the classroom.

There were numerous other occurrences related to creative content and language that would have been interesting and noteworthy but have been left out because of time and study scale limitations. 


\section{Discussion}

Several interesting findings have emerged from this experiment. First of all, it is interesting to note that the actual creative process of telling the story always stood in the foreground and the second language always had a lesser importance in the recordings for both participants. The participants produced much more commentary on the subject of story content, which is evident from the tables in the results. This could potentially point to the fact that even when the creative process takes place in the second language, the language itself remains secondary in importance within the context of creating ideas. It does not significantly interfere in the actual idea production and decision-making, and the communication of ideas remains the main focus. That might point to the fact that when those activities are utilised in the classroom, we work in an environment where students think about the message first and the grammar structures later, possibly motivating them to communicate more often, instead of dreading looming grammatical errors. This interpretation needs to be observed with caution as both students were highly proficient in English and had virtually no need to express themselves in their L1. They rarely needed to stop and think how to express something in English, so for developing any further studies it would definitely be advisable to work with first year students, as the language contemplations might be more significant as more obstruction might occur.

The decisions that drove the creative process seemed to be predominantly rooted in real world experiences, but that might have been a connection to the picture prompt which leant itself to a more realistic story. It might be a good idea to consider a less realistic picture as the prompt next time to give them an even bigger range of imaginative possibilities.

What was also very visible and evident was the fact that the participants had the desire to make the story interesting and unique. That might be their interpretation of what creativity and creative thinking actually are, or they might have had their audience in mind. In either case, it shows a level of commitment and motivation to prove their creativity. If we transfer that to the classroom, these activities might provide an opportunity to motivate our students to write in a foreign language and to use innovative ways of thinking.

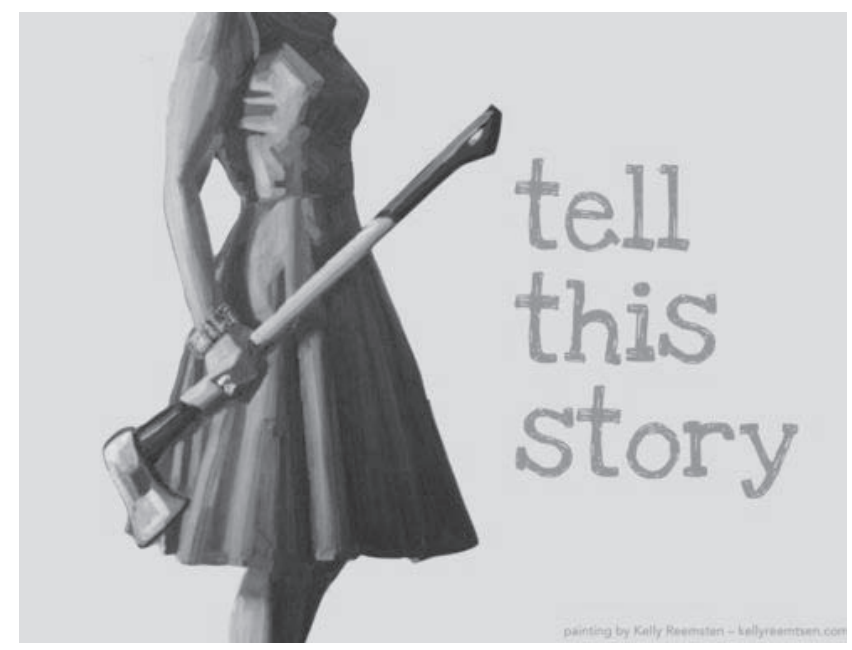

Picture 1. Picture prompt for writing (taken from: http://writingprompts.tumblr.com/ post/17477297690/my-28-most-tried-and-true-writing-prompts). 
The study naturally does have its shortcomings due to the fact that the time for its execution was very limited and that additional data collection tools, such as interviews, which could further verify the connections pointed out, were not conducted due to time limitations. The results are nonetheless valid and provide some starting thoughts into further related topics.

The correspondence with the research goals was met by observing the decisions and the reasoning behind them within the creative process and by the possible connections established with EFL learning, also pointed out and discussed with the emerging categories in the results section. We managed to establish that during the planning the content was more in the foreground of the participants thinking, and we managed to find some unified categories that indicate what drives the decision making and where it can give us indications on their learning.

\section{Conclusion}

This study was exploratory in nature. The point was to observe and begin to describe some impressions on the creative process and its connections to the ELT environment.

One facet that might be interesting to explore further is how the thinking itself behaves within the process. It seems as though several smaller interconnected processes stimulate each other into existence. One creative solution sparks a new problem or more new ways to explore and those further stimulate new decisions within that, and again trigger new contemplations. They present themselves like small units of creative thinking within one bigger unit, sparking each other into existence.

Another aspect that might be interesting to observe would be the illumination moments themselves and the emotions of the students when they reach them. One of the participants demonstrated excitement when he produced a plot development that he was pleased with and it appeared to motivate him despite the difficulty of the task. It would be interesting to see how the students' motivation is influenced by the illumination moments.

As teachers, it is our obligation to try and understand our students as best as we possibly can. Getting to know what happens within their cognition when they are creative in a foreign language could grant us additional insight into their world and give us more tools to help them become more fluent speakers. The above study gives us a glimpse into the thinking processes going on during creative writing in English as a foreign language, and it indicates what decision making potentially drives students and how this may correspond to their learning. If we manage to understand how reasoning processes in creative thinking unfold, we might be able to teach students in a way that better suits their needs.

\section{References}

Amabile, Teresa M. 1996. Creativity in Context: Update to the Social Psychology of Creativity. Boulder: Westview Press.

Boden, Margaret A. 2001. "Creativity and Knowledge." In Creativity in Education, 1st ed., edited by Anna Craft, Bob Jeffrey, and Mike Leibling, 95-102. London: Continuum.

Bowles, Melissa A. 2010. The Think-Aloud Controversy in Second Language Research. 1st ed. New York: Routledge.

Bowles, Melissa A., and Ronald P. Leow. 2005. "Studies in Second Language Acquisition.” Studies in Second Language Acquisition 27 (3): 415-40. doi:10.1017/S0272263105050187. 
Burke-Adams, Angela. 2007. "The Benefits of Equalizing Standards and Creativity: Discovering a Balance in Instruction." Gifted Child Today 30 (1): 58-63. doi:10.4219/gct-2007-16.

Cropley, Arthur J. 2001. Creativity in Education \& Learning. 1st ed. London: Routledge.

Csikszentmihalyi, Mihaly. 2009. Creativity: Flow and the Psychology of Discovery and Invention. New York: HarperCollins Publishers.

Dai, Fan. 2010. "English-Language Creative Writing in Mainland China." World Englishes 29 (4): 546-56. doi:10.1111/j.1467-971X.2010.01681.x.

Einhover, Jan E., and W. Edgar Vinacke. 1952. "Creative Processes in Painting." Journal of General Psychology 47 (2): 139-64. doi:10.1080/00221309.1952.9710660.

Ellis, Rod. 2005. "Measuring Implicit and Explicit Knowledge of a Second Language." Studies in Second Language Acquisition 27 (2): 141-72. doi:10.1017/S0272263105050096.

Ericsson, K. Anders, and Herbert A. Simon. 1993. Protocol Analysis - Rev'd Edition: Verbal Reports as Data. 2nd ed. Cambridge, MA: MIT Press.

Gass, Susan M., and Alison Mackey. 2000. Stimulated Recall Methodology in Second Language Research. 1st ed. New Jersey: Lawrence Erlbaum Associates.

Goleman, Daniel, Paul Kaufman, and Michael Ray. 1992. The Creative Spirit: Companion to the PBS Television Series. New York: Dutton.

Guilford, J.P. 1950. “Creativity.” American Psychologist 5 (9): 444-54. doi:10.1037/h0063487.

Jourdenais, Renée. 2001. “Cognition, Instruction and Protocol Analysis.” In Cognition and Second Language Instruction, edited by Peter Robinson, 254-76. Cambridge: Cambridge University Press.

Kaufman, James C., and Robert J. Sternberg, eds. 2010. The Cambridge Handbook of Creativity, 1st ed. New York: Cambridge University Press.

Kozbekt, Aaron, Ronald A. Beghetto, and Mark A. Runco. 2010. "Theories of Creativity”. In The Cambridge Handbook of Creativity, 1st ed., edited by James C. Kaufman and Robert J. Sternberg, 20-47. Cambridge: Cambridge University Press.

Mumford, Michael D., and Keith Simonton. 2011. "Creativity in the Workplace: People, Problems, and Structures.” The Journal of Creative Behavior 31 (1): 1-6. doi:10.1002/j.2162-6057.1997.tb00776.x.

Raimes, Ann. 1985. "What Unskilled ESL Students Do as They Write: A Classroom Study of Composing on JSTOR.” TESOL Quarterly 19 (2): 229-58. doi:10.2307/3586828.

Runco, Mark A., and Robert S. Albert. 2010. "Creativity Research: A Historical View.” In The Cambridge Handbook of Creativity, 1st ed., edited by James C. Kaufman and Robert J. Sternberg, 3-19. Cambridge: Cambridge University Press.

Spack, Ruth. 1985. "Literature, Reading, Writing, and ESL: Bridging the Gaps.” TESOL Quarterly 19 (4): 703-25. doi:10.2307/3586672.

Tin, T. B. 2013. "Towards Creativity in ELT: The Need to Say Something New." ELT Journal 67 (4): 385-97. doi:10.1093/elt/cct022.

Wallas, Graham. 1926. The Art of Thought. London: Jonathan Cape.

Widodo, Handoyo Puji, and Andrzej Cirocki, eds. 2013. Innovation and Creativity in ELT Methodology

(Education in a Competitive and Globalizing World), 1st ed. Hauppauge: Nova Science. 